\title{
In Reference to Risk Perception of Septic Shock with Multiple Organ Failure Due to Acute Exacerbation of an Infectious Dental Disease [Letter]
}

\author{
Yuh Baba $\mathbb{D}^{\prime}$ \\ Satoshi Takada $\mathbb{D}^{2}$ \\ Yasumasa Kato $\mathbb{D}^{3}$ \\ 'Department of Otorhinolaryngology, \\ Ohu University Dental Hospital, \\ Koriyama City, Fukushima, 963-86II, \\ Japan; ${ }^{2}$ Department of Oral and \\ Maxillofacial Surgery, Ohu University \\ Dental Hospital, Koriyama City, \\ Fukushima, 963-86II, Japan; \\ ${ }^{3}$ Department of Oral Function and \\ Molecular Biology, Ohu University School \\ of Dentistry, Koriyama City, Fukushima, \\ 963-86I I, Japan
}

\section{Dear editor}

We read with interest the article "Risk Perception of Septic Shock with Multiple Organ Failure Due to Acute Exacerbation of an Infectious Dental Disease" by Sato et al. ${ }^{1}$

In December 2019, the outbreak of coronavirus disease 2019 (COVID-19) by the severe acute respiratory syndrome coronavirus 2 (SARS-CoV-2), was reported in Wuhan, China. ${ }^{2}$ While it was recommended to postpone the treatment for patients with non-urgent diseases, emergent diseases such as peritonsillar abscess, acute supraglottitis, acute deep neck infection, and septicemia due to acute exacerbation of infectious dental disease like this case must receive emergent conservative or surgical management even during the COVID-19 pandemic. Furthermore, Takahashi et al suggested that periodontopathic bacteria promotes SARS-CoV-2 infection by increasing the expression of angiotensin-converting enzyme 2 (ACE2) which is the host cellular receptor and that pro-inflammatory cytokines such as interleukin- 6 and -8 also stimulate SARS-CoV-2 infection. ${ }^{3}$

Thus, we have serious concerns about the increase in the mortality of SARSCoV-2 by infection of the periodontopathic bacteria in this case. At first, the authors should indicate this case report before or during the COVID-19 pandemic, and also, explain the reason why the swelling spreads to the left buccal region, nevertheless pus discharge from the periodontal pocket was observed. Of course, one reason is the fact that antibiotics were not prescribed in this case. As another reason, it is possible that the abscess is not unilocular but multilocular. The abscess at masticator space frequently extends from the molar teeth, and the abscess can result in trismus, ${ }^{4}$ leading to more difficulty while eating like this case. Furthermore, deep neck abscess such as parapharyngeal space and danger space infection can lead to severe life-threatening complications such as mediastinitis and septic shock. Chest CT in this case indicated pleural effusion. Taken together, we speculate that deep neck abscess which extended from the molar teeth resulted in trismus, mediastinitis, and septic shock.

Please clarify the possible pathway of the extension from infectious dental disease to septic shock, in addition to the infecting organism. We do not know
Correspondence: Yuh Baba

Email y-baba@den.ohu-u.ac.jp 
accurate onset of sepsis in this case, although the authors speculate that "the patient's rapid progression from dental infection to dehydration and septicemia may have been related to the difficulty while eating for three days". When screening for sepsis, doctors often use the Systemic Inflammatory Response Syndrome (SIRS) or the quick Sepsis-related Organ Failure Assessment (qSOFA) or the National Early Warning Score (NEWS). Usman et al indicated that NEWS is the most useful for the early identification of sepsis out of these evaluations. ${ }^{5}$ Thus, we regret that the dentist did not evaluate NEWS daily in this case when sterilization was performed daily. We hope to hear the author's opinion at this point.

\section{Disclosure}

The authors report no conflicts of interest in this communication.

\section{References}

1. Sato H, Tamanoi T, Suzuki T, et al. Risk perception of septic shock with multiple organ failure due to acute exacerbation of an infectious dental disease. Ther Clin Risk Manag. 2021;17:365-369. doi:10.2147/ TCRM.S286764

2. Lu H, Stratton CW, Tang YW. Outbreak of pneumonia of unknown etiology in Wuhan, China: the mystery and the miracle. J Med Virol. 2020;92(4):401-402. doi:10.1002/jmv.25678

3. Takahashi Y, Watanabe N, Kamio N, et al. Expression of the SARS-CoV-2 Receptor ACE2 and proinflammatory cytokines induced by the periodontopathic bacterium fusobacterium nucleatum in human respiratory epithelial cells. Int $J$ Mol Sci. 2021;22(3):1352. doi:10.3390/ijms 22031352

4. Lim HK, Wang JM, Hung ST, Ku HC. A dangerous cause of airway obstruction: deep neck infection. Signa Vitae. 2021;17(2):4-9.

5. Usman OA, Usman AA, Ward MA. Comparison of SIRS, qSOFA, and NEWS for the early identification of sepsis in the emergency department. Am J Emerg Med. 2019;37(8):1490-1497. doi:10.1016/j. ajem.2018.10.058

Dove Medical Press encourages responsible, free and frank academic debate. The content of the Therapeutics and Clinical Risk Management 'letters to the editor' section does not necessarily represent the views of Dove Medical Press, its officers, agents, employees, related entities or the Therapeutics and Clinical Risk Management editors. While all reasonable steps have been taken to confirm the content of each letter, Dove Medical Press accepts no liability in respect of the content of any letter, nor is it responsible for the content and accuracy of any letter to the editor.

\section{Publish your work in this journal}

Therapeutics and Clinical Risk Management is an international, peerreviewed journal of clinical therapeutics and risk management, focusing on concise rapid reporting of clinical studies in all therapeutic areas, outcomes, safety, and programs for the effective, safe, and sustained use of medicines. This journal is indexed on PubMed Central, CAS,
EMBase, Scopus and the Elsevier Bibliographic databases. The manuscript management system is completely online and includes a very quick and fair peer-review system, which is all easy to use. Visit http://www.dovepress.com/testimonials.php to read real quotes from published authors. 